\title{
Aggressive competition for critical resources among migratory birds in the Neotropics
}

\author{
RUSSELL GREENBERG, JAVIER SALGADO ORTIZ and CLAUDIA \\ MACIAS CABALLERO
}

\section{Summary}

Competition between closely related species of migratory birds is thought to be important in determining their winter distributions, habitat and resource use. However, the role of active dominance interactions has generally been downplayed. In this paper we review the occurrence of interspecific feeding territories among certain Neotropical migrants. Aggressive dominants have been reported primarily at flowering plants, but also at the honeydew from scale insect infestations, the canopy of insect-rich pioneer trees and, occasionally, fruiting trees. Although the phenomenon is uncommon, aggressively dominant species may be important in certain habitats. The presence of such interspecific territorial systems argues for the poverty of resources in the habitat as a whole. Studying aggressive interactions among migrants is a way of using bird behaviour to define critical resources for conservation management.

La competencia entre especies de aves migratorias estrechamente emparentadas entre sí se considera importante para determinar su distribución invernal, hábitat y uso de recursos. Sin embargo, el papel de las interacciones de dominancia activa ha sido generalmente minimizado. En este trabajo revisamos la existencia de territorios de alimentación interespecíficos entre ciertos migrantes neotropicales. Se han observado casos de dominancia agresiva en plantas en floración, pero también en el exudado producido por las plagas de ciertos insectos, en el dosel de árboles pioneros ricos en insectos y, ocasionalmente, en árboles frutales. Aunque el fenómeno no es común, las especies dominantes agresivas pueden ser importantes en ciertos hábitats. La presencia de estos sistemas territoriales interespecíficos indica la pobreza de recursos en el hábitat. El estudio de las interacciones agresivas entre migrantes es una manera de utilizar el comportamiento de las aves para identificar recursos críticos desde el punto de vista de la conservación y el manejo.

\section{Introduction}

Research over the past 25 years has demonstrated that closely related migratory birds show considerable geographic, habitat, or trophic segregation during the 
non-breeding season. These observations are consistent with the view of Lack (1968) that winter is a limiting season for migratory species and that ecological segregation between congeners is achieved largely through geographic or habitat segregation (also see Cox 1968). Although there is general agreement that migratory birds tend to show relatively little ecological overlap, the mechanism and ultimate cause of this segregation is far from understood. The major patterns of ecological segregation are the allopatric distribution of congeners (Salomonsen 1955), as well as separation by habitat (Fitzpatrick 1980) and foraging site (Lack and Lack 1972, Rappole and Warner 1980). That interspecific competition is responsible for such patterns depends on the assumption that food resources are limiting and that migrant species interact with each other more than they do with myriad resident tropical species (Greenberg 1986). Neither of these assumptions has been tested adequately in most cases.

Competition is most easily visualized when it involves aggressive interference rather than differences in the efficiency of resource use. Considerable work has been focused on intraspecific aggression and territoriality in migratory birds in the non-breeding season (Rappole and Warner 1980, Greenberg 1984, Holmes et al. 1989), but despite this most recent reviews of habitat selection (Rappole and Warner 1980, Hutto 1985, Morse 1990) and competition (Greenberg 1986) in migratory birds have minimized the importance of direct behavioural interactions between species. In this paper, we re-examine the potential importance of interference competition in light of our own recent observations of interspecific aggression in Dendroica. We will argue that aggressive behaviour allows the identification of certain critical resources for habitat management.

\section{Aggression in winter flocks}

Because many Neotropical migrants are intraspecifically solitary, but occur in diverse mixed-species flock systems, the winter social system should provide the opportunity for interspecific interactions. However, it is the general rule that aggression is relatively uncommon and expressed at low levels of intensity in mixed-species flocks. Morse (1970) argued that seemingly low-level aggression within foraging flocks can play a major role in shaping the niche of insectivorous birds. In contrast to Morse's work in temperate forests, workers studying mixed-species flocks in tropical habitats have found little interspecific aggression and have dismissed its importance (Munn and Terborgh 1979, Powell 1980, Gradwohl and Greenberg 1980, Ewert and Askins 1991).

An exception that proves the rule for mixed-species flocks is the association of Pine Warbler Dendroica pinus and Brown-headed Nuthatch Sitta pusilla (Morse 1967). When travelling in flocks and searching for arthropods, the two species forage in distinct portions of a tree with low levels of aggression. However, when pine nuts become available, aggression increases with warblers chasing nuthatches from the proximal ends of branches. At this point, however, the association between the species and the cohesion of the mixed-species flocks tends to break down. It is likely that the presence of a rich, defendable resource is unconducive to the formation of cohesive mixed-species associations.

Another apparent exception is bird associations at ant swarms. Flushed insects can be captured at different positions with respect to the swarm and there is a sharp gradient of poor versus good positions. The latter are dominated 
Table 1. Interspecific territoriality in non-breeding Neotropical migrants

\begin{tabular}{llll}
\hline Species & Location & Resource & Subordinate \\
\hline Hummingbirds & Mexico & Flower nectar & Other hummingbirds \\
Northern Oriole & Costa Rica & Flower nectar & Small birds \\
Tennessee Warbler & Mexico & Insects & Parulinae \\
Palm Warbler & Florida, Bahamas & Flower nectar & Parulinae \\
Cape May Warbler & Bahamas, Antilles & Flower nectar fruit & Parulinae \\
Yellow Warbler & Chiapas, Mexico & Foliage arthropods & Parulinae \\
Audubon's Warbler & Chiapas, Mexico & Honeydew & Small birds \\
\hline
\end{tabular}

by the more specialized ant-following birds, which are resident species (Willis 1966). Here again, the defence of ant-swarms is similar to the defence of particular resources discussed in the next section.

\section{Interspecific territoriality}

Interspecific territoriality occurs when an individual of one species defends a specific place against individuals of other species. This phenomenon is rare and restricted to a few ecological situations, primarily in cases of all-purpose breeding territories of closely related species (Johnson 1963, Orians and Willson 1964, Catchpole 1973, Cody 1978, Rice 1978; but see Morse 1966, Sherry and Hoimes 1988) or of the aggressive defence of a patchy and valuable resource (Maurer 1984). The latter phenomenon is most important in the non-breeding season. Interspecifically defended feeding territories have been regularly reported at a highly productive feeding site, such as a nectar source (Lyon 1976, Dow 1977, Carpenter 1978, Gill and Wolf 1979), lerp and honeydew (Paton 1980, Loyn et al. 1983), sap (Foster and Tate 1966), acorn storage trees (MacRoberts 1970), and fruit (Salomonson and Balda 1977, Moore 1978).

For Neotropical migrants there are observations of a few species that feed on rich nectar sources or fruiting trees, including the Northern Oriole Icterus galbula (Schemske 1975, Cruden and Hermann-Parker 1977), Cape Mày Warbler Dendroica tigrina (Kale 1967, Leck 1972, Emlen 1973, Staicer 1992) and Palm Warbler Dendroica palmarum (Emlen 1973, Wunderle 1978) (Table 1). In addition, near Ocosingo, Chiapas, we observed Tennessee Warblers Vermivora peregrina defending a tree with high densities of homopterans against several species of wood warbler. Each of these observations recorded a high level of aggression. However, because the studies were short-term and the aggressive behaviour can often be attributed to seemingly unusual circumstances, it has been easy to dismiss interspecific territoriality as being generally unimportant.

We discuss three examples where interspecific defence of a resource is a commonplace event and an important aspect of the biology of a population or species of Neotropical migrant.

\section{Case studies}

\section{Yellow Warbler in cattle pastures of Chiapas}

With the current rapid changes in habitat in Latin America and the Caribbean, the long-term fate of migratory bird populations in part depends on their 
response to this anthropogenic change. Along the settlement frontier, we can observe how new habitats are colonized by different bird species and which mechanisms determine successful colonization and control population levels.

We have been conducting research in the Lacandon forest, which is one of the last major frontiers of development in southern Mexico. In the past 15 years (mid-1970s to 1992), seven ejidos (rural land cooperatives) were formed along the southern shore of the Río Lacantun and down to the Guatemalan border (Márquez de Comillas). The people of these rural communities have cultivated river-front land and grazed cattle on land away from the river. Therefore, in stark contrast to the natural forest habitats on the north side of the river, the Márquez de Comillas offers an expanding sea of a man-formed savanna with trees dotting the pastures and forming narrow ribbons of woods along arroyos.

The pastures themselves support low populations of open-country species. The majority of migratory birds occupy the patches of trees, which cover approximately $5-10 \%$ of the land surface. Densities of birds, particularly of migrants, can be high in these remnants. However, we believe that resources are quite limited and aggressive competition for this newly formed habitat is quite intense.

The major conflict over this habitat occurs between two of the commonest species of Dendroica (for details see Greenberg and Salgado Ortiz in press). Yellow Warblers $D$. petechia defend small territories in isolated patches of trees in cattle pastures. Interspecific aggression by Yellow Warblers was observed far more frequently than intraspecific aggression. Although it was directed toward at least 40 species, resident and migrant alike, attacks on a single species Magnolia Warblers D. magnolia - comprised $35 \%$ of the total observed.

During 54 hours of focal observations of individual Yellow Warblers we observed long-distance aggressive chases averaging once every 12 minutes. Aggression consisted primarily of long-distance attacks (initiated from an average of $9 \mathrm{~m}$ away), which occasionally ended with physical contact. This represents a high level of overt interspecific aggression. The frequency of interaction resulted from two different factors: the high rate of response of Yellow Warblers and the high frequency of "testing" of the Yellow Warbler's territory by the subordinate species. Individuals of subordinate species often spent much of their time in shrubbery, hedgerows, or the lowest branches of trees, flying or climbing into the canopy whenever the Yellow Warbler left the tree or the patch of trees.

Both the low threshold for aggression and the high frequency of testing by subordinates suggest that the canopy of pasture trees represents a resource with rich food resources. This suggestion is logical, since the pasture vegetation is dominated by fast-growing "pioneer" species that are highly productive and have relatively palatable leaves (Coley 1982). The hypothesis that Yellow Warblers are defending an area of high food density was supported by the high density of insects in canopy versus understorey vegetation on Yellow Warbler territories. We counted arthropods on the first 1,250 leaves encountered on transects in the canopy and understorey of four Yellow Warbler territories, and found densities were twice as high in the canopy. We compared the foraging manoeuvre rate of the two species in 60 two-minute focal observations and found them to be similar. However, the proportion of large arthropods cap- 
tured, primarily caterpillars, was almost an order of magnitude higher in Yellow Warblers (30\%) than Magnolia Warblers (4\%) foraging on the same territories.

The questions remain: do Yellow Warblers defend the canopy of pasture trees because the tree crowns support high insect populations, or are insect populations higher in the canopy because Yellow Warblers defend the crowns and reduce the overall predation pressure on arthropods (see Loyn et al. 1983)? We conducted an exclosure experiment which showed that birds (primarily migrants) reduce insect densities by over $50 \%$ for all foliage sampled (Greenberg and Salgado in press). However, the reduction was significantly greater in the understorey than in the canopy trees where territorial Yellow Warblers resided. This experimental result supports the idea that the higher insect densities are a result of the defence by Yellow Warblers. Perhaps it is purely the structure of the canopy as opposed to that of the understorey that makes it easier to defend.

This study does not establish how widespread interspecific territoriality is in wintering Yellow Warblers. If it is of common occurrence, it has implications for habitat use and social systems of other migrants in patches of second growth. The subordinate Magnolia Warbler lives in most habitats in the Lacandon forest, but becomes progressively commoner as one moves from pasture to scrub to forest. In the less preferred pasture habitat, we made observations on nine colour-marked individuals, in addition to a number of individuals recognizable by plumage characteristics, from October until their disappearance or the end of winter. Individuals maintained largely exclusive home-ranges. During the early part of the winter, we found a one-to-one correspondence between the core area of a Magnolia Warbler and a Yellow Warbler territory. We have some evidence that Magnolia Warblers maintain a territorial system with less overt aggression. The coincidence of the core home-range with individual Yellow Warblers is a phenomenon worthy of further study. In light of the aggression suffered by Magnolia Warblers, it is hard to see the advantage of maintaining as association with a particular Yellow Warbler. Perhaps the association facilitates the learning of escape routes, as well as of behavioural idiosyncracies of the dominant Yellow Warbler.

Based on fieldwork in Veracruz, Mexico, Rappole and Morton (1985) argued that forest migrants that maintain small populations in cleared areas tend to have non-territorial spacing systems, with high population turnover because resource levels are low or unpredictable. At our Chiapas site, observations of Magnolia Warblers and other forest migrants with small, long-term territories belie this explanation. However, the same aggressive behaviour suggests an alternative hypothesis for extensive home-range overlap in small migratory birds. We suggest that species such as Magnolia and Wilson's Warblers Wilsonia pusilla move between Yellow Warbler territories because they are chased or in order to locate areas where Yellow Warblers are absent.

The gestalt of the common man-created winter habitat (e.g. city parks, pastures, villages, etc.) of the Yellow Warbler contrasts with breeding habitat in generally having a clear open understorey. Its natural flood-plain winter habitat has a similar structure. This conclusion is based on observations along the less disturbed north shore of the Río Lacantun, where Yellow Warblers occur in a narrow band of riparian vegetation. This vegetation has a willow Salix canopy and a cane or bamboo or open sand-bar understorey. 
In pasture habitats, the subordinate species often drop into any available dense vegetation when attacked by Yellow Warblers. This suggests that scrub or hedgerow vegetation provides a critical refuge for subordinate, migratory birds. Given the great extent of cattle pasture in lowland Mesoamerica, small changes in habitat management on pastures may have a large effect on the carrying capacity for migratory birds. The observations in this study suggest that the maintenance of hedgerow vegetation may provide critical refugia for many migratory species and allow them some access to the highly productive canopy trees.

\section{Audubon's Warblers in oak woodlands}

In a high elevation oak Quercus woodland near San Cristóbal de las Casas, Mexico, Vidal-Rodríguez (1992) and Macias (in prep.) reported extraordinarily high levels of interspecific aggression involving Audubon's Warblers Dendroica coronata and a somewhat lower amount of aggression between Townsend's $D$. townsendi and Wilson's Warblers. The probability of a Townsend's or Wilson's Warbler being attacked was strongly related to foraging height (Macias in prep.). When this paper was originally presented at the Neotropical Ornithological Congress in Quito (November 1991), we believed that the aggression was related to vertical stratification, with Audubon's Warbler, the largest species, dominating the canopy against the smaller Townsend's Warbler, which in turn aggressively defended the mid-strata from the diminutive Wilson's Warbler.

However, further study (Greenberg et al. 1993) has determined that the competition involves the defence of secretions of a scale insect (family Margoraridae). Audubon's Warblers aggressively defend patches of 1-5 infected trees (approx. $300 \mathrm{~m}^{2}$ ) throughout the winter against other species of warblers and hummingbirds; they also defend flowering Sterculia trees. Individual Audubon's Warblers were followed on 13 territories for 2-7 hours (total of 65 hours) distributed equally between mornings and afternoons in November, December and January, and were identified by making detailed notes of their highly variable plumage. Warblers chased birds of other species from an average distance of $8.5 \mathrm{~m}$, once every five minutes. Audubon's Warblers chased adult male Townsend's Warblers 90\% of the time, which in turn chased dominant female and immature conspecifics and other wood warbler species. Although the defence of honeydew and other homopteran exudates is widespread in Australian and New Zealand birds and mammals (Paton 1980, Gaze and Clout 1983), their use has only rarely been reported for the Neotropics (Greenberg et al. 1993 and references therein).

The scale insects live in pits or fissures in the bark and produce a hair-like white thread which protrudes $1.5-8 \mathrm{~cm}$ from the branch and reaches densities of one per $\mathrm{cm}^{2}$. Scale insects produce honeydew throughout the day, with volumes ranging from 0.2 to $1.9 \mu \mathrm{l} \mathrm{per} / \mathrm{hr}$ depending on time of day and temperature. Sucrose concentrations range from $19-55 \%$ (higher concentrations were not measurable with the refractometer we used).

Groups of Audubon's Warbler territories have been found in the same localities on Cerro Huitepec between 1987 and 1992 (R. Vidal pers. comm.). We observed the same territories being defended throughout the winter of 19911992. The patches of oaks with scale insects and the attendant birds are widely 
distributed in the oak and pine-oak woodlands of the central meseta of Chiapas. We surveyed several widely separated areas and found an average of 3.4 Audubon's Warbler territories per $\mathrm{km}$ censused (along $10 \mathrm{~km}$ transects). Audubon's Warblers were always associated with the scale insect. The composition of the birds associated with the scale insects was quite consistent from patch to patch. Each of the 13 focal territories, and all of the 37 territories surveyed, had at least one adult male Townsend's Warbler in association. When the Audubon's Warbler was absent, male Townsend's Warblers were dominant. Three-quarters of the territories had a Wilson's Warbler. Most of the territories had a female or immature male Townsend's Warbler that spent its time primarily in the understorey. Other common associates were White-eared Hummingbirds Hylocharis leucotis, Nashville Warblers Vermivora ruficapilla, Painted Myioborus picta and Slate-throated Redstarts M. miniatus and Yellow-bellied Sapsuckers Sphyrapicus varius.

\section{Cape May Warblers}

Cape May Warblers have been repeatedly reported to defend small interspecific territories associated with nectar sources (Kale 1967, Emlen 1973, Sealy 1989a) or fruit (Leck 1972, E. S. Morton pers. comm.). In addition, many researchers on the large Caribbean Islands have noted the aggressive tendencies of Cape May Warblers (Post 1978, A. Stockton de Dod pers. comm., E. S. Morton pers. comm). Staicer (1992) offers the first data on marked individuals. The aggressive territorial behaviour was not an ephemeral phenomenon, but occurred in most individuals for the entire winter. Although densities were low (approximately one/ha), the activity of individuals was associated with a few flowering Prosopis trees. Long-distance chases were observed at an average frequency of one every 3.5 minutes. As in the case of the Audubon's and Yellow Warblers, Cape May Warblers allowed subordinate species in the understorey, but attacked them when they entered the canopy. Subordinates were primarily other species of Parulinae, principally the migratory Northern Parula Parula americana and Prairie Warblers Dendroica discolor. Chases were also directed toward the resident Adelaide's Warbler Dendroica adelaidae, Bananaquit Coereba flaveola and Antillean Euphonia Euphonia musica. As in the other interspecific territorial systems discussed above, the subordinate species were generally smaller than the Cape May Warblers.

Interspecific aggression and territoriality has been reported in many circumstances for the Cape May Warbler. In addition to the reports from the species's West Indian wintering grounds, interspecific territoriality has been reported for both nectar and arthropods (in this case aquatic insects) on migration (Sealy 1989b). R.G. (unpublished data) has observed male Cape May Warblers chasing other wood warblers from the top of conifers on their breeding grounds, targeting any small bird that flew within $20 \mathrm{~m}$ of its tree. This high level of aggression is also displayed by Cape May Warblers kept in mixed exhibits in captivity, where ad libitum food sources are defended against a range of other species (R.G. pers. obs.).

This brief review is probably an underestimate of the frequency of interspecific territoriality in this species. High levels of aggression are so commonly observed in Cape May Warblers that many observations go unpublished. 
Table 2. A comparison of long-term interspecific territories in three species of Dendroica

\begin{tabular}{lccc}
\hline & YELLOW & AUDUBON'S & CAPE MAY \\
\hline Location & Mexico & Mexico & Puerto Rico \\
Habitat & Pasture & Oak woodland & Dry forest \\
Duration & All winter & All winter & All winter \\
Size & $500 \mathrm{~m}^{2}$ & $300 \mathrm{~m}^{2}$ & $?$ \\
Resource & Arthropods & Honeydew & Nectar \\
Rates of chases & $10 / \mathrm{hr}$ & $20 / \mathrm{hr}$ & $17 / \mathrm{hr}$ \\
Distance from target & $9 \mathrm{~m}$ & $8 \mathrm{~m}$ & Long \\
at which chase begins & & & 6 \\
Species chased & $40+$ & 10 & 80 \\
$\%$ migrant & 79 & 95 & 96 \\
$\%$ Parulinae & 69 & 93 & 20 \\
$\%$ intraspecific & $\mathbf{1}$ & 0 & Nownsend's \\
Most commonly chased & Magnolia & & Parula \\
species & & Townsthern & \\
\hline
\end{tabular}

\section{Discussion}

\section{The adaptive significance of non-breeding interspecific territoriality}

Several hypotheses have been proposed for the function (or lack thereof) of interspecific territorial behaviour (Murray 1971, Sherry and Holmes 1988). Because the three species of wood warbler described above were defending winter feeding territories, hypotheses relating to breeding and nesting do not apply (see Table 2). Two major hypotheses remain: that interspecific aggression benefits warblers by maintaining high food levels, the increase in standing crop of food offsetting the energetic cost of chasing (Carpenter 1978, Gill and Wolf 1979); or that the behaviour is a non-adaptive carry-over from situations when aggression is adaptive (Murray 1971, Emlen 1973). The resolution of the nonadaptive versus adaptive nature of interspecific aggression is not an esoteric exercise, but may have major implications for the usefulness of the observations of aggression in identifying critical resources. If the behaviour is adaptive, then the defence of a resource provides prima facie evidence that the defended resource is a critical one.

Several observations argue against the non-adaptive explanation. (1) Intraspecific chasing is rare compared with interspecific. (2) The rate of interspecific chasing remains high throughout the winter, despite the rarity of intraspecific chasing. (3) A range of species, very different in appearance from the aggressive dominant, was attacked. (4) In two cases, the level of aggression was higher against conspecific interlopers than heterospecific, indicating that even in highspeed chases the distinction is made. (5) In the cases of Yellow and Audubon's Warblers, high rates of chasing, either intra- or interspecific, have not been reported for other times of the year (Morse 1990). On the other hand, the presence of either nectar, honeydew or a high frequency of capture of large caterpillars (as in the case of the Yellow Warbler) suggests that in each case the dominant is defending rich patches of food. This is the circumstance in which overt interference competition should occur (Maurer 1984). The behaviour of the subordinate species also sheds doubt on the proposal (by Emlen 1973) that the aggressive behaviour of the dominants is an inappropriate response. The high 
rate of intrusion of the subordinates in the face of aggression suggests that the defended resource is truly valuable.

An additional criterion for considering an interspecific territorial system as adaptive is the selectivity of victims (Lyon et al. 1977, Moore 1978). The prediction is that the aggressive species should preferentially attack species that are competitors. In the case of the Yellow Warbler, the probability of attack was based largely on the competitor's size, which was highly correlated with the probability of expelling the intruder. Within the proper size category, the sample size of non-insectivorous species was too small to determine if they were chased less frequently. However, since such a high proportion of birds were potential competitors, it may be marginally advantageous to make the distinction. Wunderle (1978) found that an interspecifically aggressive Palm Warbler only chased birds of comparable or smaller size. Audubon's Warblers also chased small birds indiscriminately. In the latter case, all visitors to the oak trees were observed feeding on the honeydew and were potential competitors.

\section{Four characteristics of interspecific territoriality in Neotropical migrants}

(1) Defence occurs at island-like resources. In the Yellow Warbler, the patches of trees are like islands in an otherwise unused habitat. The Yellow Warbler appears to specialize on and dominate highly productive habitats, such as riparian trees and shrub marshes, both on the breeding and wintering grounds. The insect-infested trees used by Audubon's Warblers are also a resourc $\odot$ island in a generally depauperate habitat. This fact suggests that in these habitats resources are generally poor, making the use of these resource islands worth the risk of encountering an aggressive dominant.

There are few species of aggressive dominants. This might suggest that the phenomenon is not of great import to the ecology of migratory birds in the winter. However, if our observations of Yellow and Audubon's Warblers are characteristic of these species in their respective study habitats (lowland pastures, pine-oak woodland), then the area where aggressive dominants play a controlling role of key resources is a vast area of Mesoamerica and the Caribbean.

(2) The amount of defence and challenge to defence at these key resources suggests the general poverty of alternative resources. Emlen (1973) recognized the potential implication of interspecific dominance of a single resource. In arguing that the interspecific aggression was non-adaptive, he also argued that the general abundance of insectivorous birds in the habitat made the defence of a single nectar source by an insectivorous bird inappropriate. Schemske (1975) correctly pointed out that Emlen did not present any data on the relative abundance of insectivorous birds or their arthropod prey. Schemske proposed that such aggression did argue for the general limitation of food for migratory birds.

(3) Interspecific territoriality may be a regular feature of species. This is most clearly the case with Cape May Warblers, in which individuals of both sexes have been found to be interspecifically aggressive under a range of situations. We found Yellow Warblers to be interspecifically territorial in all habitats they occupied in the Lacandon Forest. This includes the riparian formations that probably constitute their natural habitat. A scattering of reports communicated to us from 
localities as far afield as Amazonian Peru suggests the behaviour may be widespread. Resident Yellow Warblers in Jamaica have also been observed to be interspecifically aggressive (T. Sherry and P. Marra pers. comm.). However, no other published study of this widespread and frequently observed species has noted this behaviour. Based on R.G.'s extensive experience with Audubon's Warblers, it would appear that the interspecific defence of territories is not common outside of the situations described here. However, pine-oak woodland may be the most extensive habitat type in Mexico and the oaks favoured by the scale insect are among the most widespread species in Mexico. Therefore, it is possible that this is a widespread phenomenon. There are still too few reports to evaluate the importance of interspecific territoriality in the other species of Neotropical migrants (Palm Warbler and Northern Oriole).

(4) Interaction tends to be among closely related migrants. This makes it a potentially important mechanism in ecological segregation among closely related migrants. An example of this might be the interaction between Cape May Warblers. Northern Parulas are commonly nectarivorous in the dry season in the Yucatán Peninsula (Greenberg 1992), yet use of flowers is almost unreported for the Antilles. It is possible that the dominance of Cape May Warblers on the islands prevents Northern Parulas from using nectar resources. Cape May Warblers are rare and restricted to coastal scrub vegetation on the Yucatán Peninsula (Lynch 1989).

\section{Interspecific defence and the identification of key resources}

Recently, work on tropical ecosystems has focused on keystone resources (Terborgh 1986). We suggest that interspecific territorial systems focus on such resources. Maurer (1984) hypothesized that active interference competition should occur at stable, concentrated and abundant resources. However, such resources must be assessed by birds in comparison to the background level of food availability. Because these interspecific systems involve the assessment of resources by numerous species, they should be found at resources that are important to the community as a whole. These systems might provide a behavioural assay of particularly important resources that might be "managed" for maintaining migratory bird populations in a particular habitat.

Although only a few such resources have been identified (i.e. scale insect honeydew, tree patches in pastures, Agave blossoms, Erythrina flowers), we believe that interspecific territorial systems may be commoner than these few reports suggest. Despite the fact that aggression occurs as often as once every three to five minutes, the behaviour is surprisingly easy to overlook. C. Staicer (pers. comm.) found that while conducting general fieldwork she recorded aggression by Cape May Warblers at a rate of less than $0.5 / \mathrm{hr}$. This is far lower than the rate of 3.5/ $\mathrm{hr}$ she recorded when following focal individuals. This underscores the fact that careful behavioural observation may provide an important tool for obtaining insights into the ecological requirements of migratory birds.

\section{Acknowledgements}

Cindy Staicer provided both unpublished data and insights on the behaviour of the Cape May Warbler. Doug Morse and Joe Wunderle made valuable sugges- 
tions on an earlier draft. We thank Rodrigo Medellín, Director of the Chajul Biological Field Station, the Centro de Ecología (UNAM), and PRONATURAChiapas for providing logistical support for the study. SEDUE allowed access to the Montes Azules Biosphere Reserve and vicinity, and the Ejidos of Chajul and Loma Bonita permitted us to conduct fieldwork on their lands. Financial support was provided by the National Fish and Wildlife Foundation, National Geographic Grants for Exploration and Research, Scott Neotropical Fund of the Lincoln Park Zoo, and the Scholarly Studies Program of the Smithsonian Institution. Field assistance was provided by Robert Reitsma and Peter Bichier.

\section{References}

Carpenter, F. L. (1978) A spectrum of nectar-feeding communities. Amer. Zool. 18: 809818.

Catchpole, C. K. (1973) Conditions of co-existence in sympatric populations of Acrocephalus warblers. J. Anim. Ecol. 42: 623-635.

Cody, M. L. (1978) Habitat selection and interspecific territoriality among the sylviid warblers of England and Sweden. Ecol. Monogr. 48: 351-396.

Coley, P. D. (1982) Rates of herbivory on different tropical trees. Pp.123-132 in E. G. Leigh, A. S. Rand and D. Windsor, eds. The ecology of a tropical forest. Washington, D.C.: Smithsonian Institution Press.

Cox, G. (1968) The role of competition in the evolution of migration. Evolution 22: 180192.

Cruden, R. W. and Hermann-Parker, S. M. (1977) Defense of feeding sites by orioles and hepatic tanagers in Mexico. Auk 94: 594-596.

Dow, D. D. (1977) Indiscriminant interspecific aggression leading to almost sole occupancy of space by a single species of bird. Emu 77: 115-121.

Emlen, J. T. (1973) Territorial aggression in wintering warblers at Bahama agave blossoms. Wilson Bull. 86: 71-74.

Ewert, D. and Askins, R. (1991) Flocking behavior of migratory warblers in winter in the Virgin Islands. Condor 93: 864-869.

Fitzpatrick, J. (1980) Wintering of North American tyrant flycatchers. Pp.67-79 in A. Keast and E. S. Morton, eds. Migrant birds in the Neotropics: ecology, behavior, distribution, and conservation. Washington, D.C.: Smithsonian Institution Press.

Foster, W. W. and Tate, J. (1966) The activities and coactions of animals at sapsucker trees. Living Bird 5: 87-113.

Gaze, P. D. and Clout, D. (1983) Honeydew and its importance to birds in beech forests of South Island, New Zealand. New Zealand J. Ecol. 6: 33-37.

Gill, F. B. and Wolf, L. L. (1979) Nectar loss by Golden-winged Sunbirds to competitors. Auk 96: 448-46r.

Gradwohl, J. and Greenberg, R. (1980) The formation of antwren flocks on Barro Colorado Island. Auk 97: 385-396.

Greenberg, R. S. (1984) The winter exploitation systems of Bay-breasted and Chestnutsided Warblers in Panama. Univ. Calif. Publ. Zool.: 1-107.

Greenberg, R. S. (1986) Competition in migrant birds in the non-breeding season. Curr. Orn. 3: 281-307.

Greenberg, R. S. (1992) Forest migrants in non-forest habitats on the Yucatan Peninsula. Pp.273-286 in J. M. Hagan and D. W. Johnston, eds. Ecology and conservation of Neotropical migrant landbirds. Washington, D.C.: Smithsonian Institution Press.

Greenberg, R. S. and Salgado Ortiz, J. (in press) Interspecific territoriality in Yellow Warblers. Auk. 
Greenberg, R. S., Macias Caballero, C. and Bichier, P. (1993) Defense of homopteran honeydew by birds in the Mexican highlands and other warm temperate forests. Oikos 68: 519-524.

Holmes, R. T., Sherry, T. and Reitsma, L. (1989) Population structure and territoriality and overwinter survivorship of two migrant warbler species in Jamaica. Condor 91: 545-561.

Hutto, R. (1985) Habitat selection by non-breeding migratory landbirds. Pp.455-476 in M. L. Cody, ed. Habitat selection in birds. New York: Academic Press.

Johnson, N. K. (1963) Biosystematics of sibling species of flycatchers in Empidonax hammondi-oberholseri-wrightii complex. Univ. Calif. Publ. Zool. 66: 79-238.

Kale, H. W. (1967) Aggressive behavior by a migrating Cape May Warbler. Auk 84: 120121.

Lack, D. (1968) Partial migration and natural selection. Oikos 19: 1-9.

Lack, D. and Lack, P. (1972) Wintering warblers in Jamaica. Living Bird 11: 129-153.

Leck, C. (1972) Observation of birds at Cecropia trees in Puerto Rico. Wilson Bull. 84:490502.

Loyn, R. H., Runnals, R., Forward, G. and Tyers, J. (1983) Territorial Bell Miners and other birds affecting populations of insect prey. Science 221: 1411-1413.

Lynch, J. (1989) Distribution of overwintering Nearctic migrants in the Yucatan Peninsula. I: General pattern of occurrence. Condor 91: 515-545.

Lyon, D. L. (1976) A montane hummingbird territorial system in Oaxaca, Mexico. Wilson Bull. 88: 281-299.

Lyon, D. L., Crandall, J. and McKone, M. (1977) A test of the adaptiveness of interspecific territoriality in the Blue-throated Hummingbird. Auk 94: 448-454.

MacRoberts, M. H. (1970) Notes on the food habits and food defense of the Acorn Woodpecker. Condor 72: 196-204.

Maurer, B. (1984) Interference and exploitation in bird communities. Wilson Bull. 93: 478490.

Moore, F. (1978) Interspecific aggression: towards whom should a mockingbird be aggressive? Behav. Ecol. Sociobiol. 3: 173-176.

Morse, D. H. (1966) The context of songs in the Yellow Warbler. Wilson Bull. 78: 444455 .

Morse, D. H. (1967) Foraging relationships of Brown-headed Nuthatches and Pine Warblers. Ecology 48: 94-106.

Morse, D. H. (1970) Ecological aspects of some mixed-species foraging flocks of birds. Ecol. Monogr. 40: 119-168.

Morse, D. H. (1990) American warblers. Cambridge, U.S.A.: Harvard University Press.

Munn, C. and Terborgh, J. (1979) Multi-specific territoriality in Neotropical foraging flocks. Condor 81: 338-347.

Murray, B. G. (1971) The ecological consequences of interspecific territorial behavior in birds. Ecology 52: 414-423.

Orians, G. H. and Willson, M. F. (1964) Interspecific territories of birds. Ecology 45: 736745 .

Paton, D. C. (1980) The importance of manna, honeydew and lerp in the diet of honeyeaters. Emu 80: 213-226.

Post, W. (1978) Social organization and foraging behavior of warblers wintering in Puerto Rican coastal scrub. Wilson Bull. 90: 197-214.

Powell, G. V. N. (1980) Migrant participation in Neotropical mixed species flocks. Pp. $477-48 j$ in A. Keast and E. S. Morton, eds. Migrant birds in the Neotropics: ecology, behavior, distribution, and conservation. Washington, D.C.: Smithsonian Institution Press.

Rappole, J. and Morton, E. S. (1985) Effects of habitat alteration on a tropical forest community. Orn. Monogr. 36: 1013-1021. 
Rappole, J. and Warner, D. (1980) Ecological aspects of migrant bird behavior in Veracruz, Mexico. Pp.353-393 in A. Keast and E. S. Morton, eds. Migrant birds in the Neotropics: ecology, behavior, distribution, and conservation. Washington, D.C.: Smithsonian Institution Press.

Rice, J. (1978) Ecological relationships of two interspecifically territorial vireos. Ecology 59: $526-538$.

Salomonsen, F. (1955) The evolutionary significance of bird migration. Biol. Medd. (Dansk) 22: $1-62$.

Salomonson, M. G. and Balda, R. P. (1977) Winter territoriality of Townsend's Solitaires (Myadestes townsendi) in a Pinon-Juniper-Ponderosa Pine ecotone. Condor 79: 148-162.

Schemske, D. W. (1975) Territoriality in a nectar feeding Northern Oriole in Costa Rica. Auk 92: 594-595.

Sealy, S. G. (1989a) Defense of nectar sources by migrating Cape May Warblers. J. Field Orn. 6o: 89-93.

Sealy, S. G. (1989b) Aggressiveness in migrating Cape May Warblers: defense of an aquatic food source. Condor 90: 271-274.

Sherry, T. W. and Holmes, R. T. (1988) Habitat selection by breeding American Redstarts in response to a dominant competitor, the Least Flycatcher. Auk 105: 350-364.

Staicer, C. A. (1992) Social behavior of the Northern Parula, Cape May Warbler, and Prairie Warbler wintering in second-growth forest in southwestern Puerto Rico. Pp. $380-320$ in J. M. Hagan and D. W. Johnston, eds. Ecology and conservation of Neotropical migrant landbirds. Washington, D.C.: Smithsonian Institution Press.

Terborgh, J. (1986) Keystone plant resources in the tropical forest. Pp.330-344 in M. E. Soulé, ed. Conservation biology. Sunderland, Mass.: Sinauer Associates.

Vidal-Rodríguez, R. M. (1992) Abundance and seasonal distribution of Neotropical migrants during autumn in a Mexican cloud forest. Pp. 370-376 in J. M. Hagan and D. W. Johnston, eds. Ecology and conservation of Neotropical migrant landbirds. Washington, D.C.: Smithsonian Institution Press.

Willis, E. O. (1966) The role of migrant birds at swarms of army ants. Living Bird 5: 187231.

Wunderle, J. (1978) Territorial defense of a nectar source by a Palm Warbler. Wilson Bull. 90: 297-299.

RUSSELL GREENBERG

Smithsonian Migratory Bird Center, National Zoological Park, Washington, D.C. 20008, U.S.A.

JAVIER SALGADO ORTIZ

Universidad Michoacana de San Nicolas de Hidalgo, Morelia, Michoacán, Mexico.

CLAUDIA MACIAS CABALLERO

Instituto de Ciencias y Artes de Chiapas, Tuxtla Guttiérez, Chiapas, Mexico. 